\title{
The Relationship between Working Capital Management and Financial Sustainability of Selected Christian Denominations in Ghana
}

\author{
Williams Kwasi Peprah ${ }^{1}$, Isaac Anowuo ${ }^{2} \&$ Daniel Adofo Kwakye Ameyaw ${ }^{3}$ \\ ${ }^{1}$ School of Business, Valley View University, Oyibi, Accra, Ghana \\ ${ }^{2}$ Ph.D. of Commerce Student, Adventist University of the Philippines, Puting Kahoy, Silang, Cavite, Philippines \\ ${ }^{3}$ Ph.D. of Commerce Student, Adventist University of the Philippines, Puting Kahoy, Silang, Cavite, Philippines \\ Correspondence: Williams Kwasi Peprah, School of Business, Valley View University, Oyibi, Accra, Ghana.
}

Received: May 6, 2019

Accepted: July 8, 2019

Available online: July 26, 2019

doi:10.11114/afa.v5i2.4410

URL: https://doi.org/10.11114/afa.v5i2.4410

\begin{abstract}
Management of working capital is a fundamental aspect of finance. This is because it affects the church's liquidity and financial sustainability. The study sort of establishing the relationship between working capital and financial sustainability for selected Christian denominations in Ghana. Using bivariate correlation application in SPSS 23, the financial statements from 2013 to 2017 of 15 Christian Council of Ghana denominational members conveniently sampled and analyzed. Working capital is represented by liquidity ratios of current ratio, and cash ratio and financial sustainability are epitomized by self-support. The study revealed that there was a positive relationship between working capital and financial sustainability among Christian denomination in Ghana. In a detailed outcome, there was a statistically small positive significant relationship between self-support and cash ratio and statistically large positive significant relationship between self-support and current ratio. The study recommends to churches in Ghana to seek an enhancing relationship between their working capital and financial sustainability to prevent a possible closure of the church. Not-for-profit organizations must seek self-support through income generation and diversification to improve their Liquidity. Again, not-for-profit organizations must have a positive relationship between working capital and financial sustainability in that churches exist because of liquidity.
\end{abstract}

Keywords: working capital, financial sustainability, liquidity ratio, current ratio, cash ratio, self-support

\section{Introduction}

Management of working capital is a fundamental aspect of finance. This is because it affects the church's liquidity and financial sustainability. Understanding the management of churches' working capital and how it is linked to self-support is paramount. There is the notion that no money no church (Bradford Wilcox, Cherlin, Uecker \& Messel, 2012).

According to IBIS World (2019), the industry of religious organizations in the United States of America consists of organizations providing religious worship or promoting religious activities. Industrial establishments are consisting of temples, churches, synagogues, mosques and other worship houses, and monasteries, convents, and community centers that are religiously affiliated. The industry has performed well over the five years up to 2018. Revenue estimation grew by an annualized 3.7 percent over the five years to $\$ 136.8$ billion in 2018. This is measured in total donations to religious organizations. By 2018 alone, with an increase of 5.3\%. The vast majority that is $69.9 \%$ of donations are made by individuals. In 2019 , the revenue went up by $2.9 \%$ to $\$ 141$ billion. However, the fear is that as revenue increases, attendance continues to decrease.

Bradford Wilcox, Cherlin, Uecker, and Messel (2012), have asserted that churches suffered financial sustainability during the recessions and it implied that no money no church. The economic condition of the church members influences financial sustainability. The members' donation provides working capital for the church and thus churches financial sustainability.

Christianity is the largest religious group in the world. Hackett and Mcclendon (2017) posit that the global representation of religion consists of $31.2 \%$ Christianity, $24.1 \%$ Muslims, $16 \%$ unaffiliated, $15.1 \%$ Hindus, $6.9 \%$ Buddhists, 5.7\% Folk religion, $0.2 \%$ Jews and $0.8 \%$ are other religion. In the same vein, Ghana statistical service 2010 census showed that $71.2 \%$ are from various Christian's denominations and only 62 are churchgoers (Van Gyampo, 
2015). The Christian religion in Ghana plays a vital role in the socio-economic development of Ghana. Therefore, their working capital management must support their mission.

Working capital management is predicated on the ratio of liquidity. It entails controlling and planning current assets and current liabilities in a manner that, on the one hand, eliminates the risk of failure due to short-term obligations and, on the other, prevents high investment in these assets (Darkwah, Nortey, Asare-Kumi \& Asare, 2019). This is because there are current assets and current liabilities. The word ' current ' means that churches must focus on their management within one year to achieve the best sustainable outcome.

Peprah, Balila, Mbokani, Evinta, and Riziki (2019) have stated that financial sustainability is the ability of the church to be able to cover its current and future expenses. To the Christian denominations, financial sustainability is a measure of self-support (Iwu, Kapondoro, Twum-Darko \& Tengeh, 2015). Self-support is total income divided by total expenses. Financial sustainability is achieved when there is at least an equilibrium continually for the foreseeable future (Leibson, 2005; Helen \& Samujh, 2011). Self-support is denoted as self-reliance from surplus or profitability (Iwu, Kapondoro, Twum-Darko \& Tengeh, 2015).

There have been various studies (Abor, 2005; Amidu, 2007; Agyei \& Yeboah, 2011; Akoto, Awunyo-Vitor \& Angmor, 2013; Yeboah \& Yeboah, 2014; \& Peprah, W. K. \& Riziki, 2019) in determining the relationship working capital and profitability in Ghana but there has not been any study to explore the same relationship of working capital and financial sustainability among Christian denominations in Ghana. This research paper has found the knowledge in the gap to address the working capital relationship with financial sustainability among selected Christian denominations in Ghana. The research question for this study is:

1. Is there a significant relationship between working capital and financial sustainability?

\section{Literature Review}

Financial sustainability is essential to a church functionality and ability to survive and cannot be accomplished in seclusion. There is a need to undertake a performance assessment in order to realize the potential of the church to become financially stable. There is, however, a narrow difference between financial sustainability and financial self-support (Leon, 2001). Financial sustainability, in particular, ensures an organization's longevity whereas financial self-support means handling operations without requesting financial support. Sustainability of the church is often linked to its financial health, but over time, financial sustainability is inadequate. Its overall capabilities need to be developed. A sustainable church can survive on a long-term basis when they generate additional income aside from the donations from church members (Dumestre, 2016).

Financial sustainability is therefore achieved if the church can cover the relevant funding costs. It also includes all the church elements and functional areas and major decisions that should be considered in modeling church sustainability (Njeri, Namusonge \& Mugambi 2017). The pillars of financial sustainability consist of sound administration, financial and strategic planning, own income generation, and income diversification (León, 2001).

Working capital management is the management of church liquidity. The analysis of the liquidity of the church is done by determining the current ratio and the cash ratio. The current ratio is a method of measuring the church's ability to finance its debt within one year (Prempeh, 2018). The cash ratio is a measure of marketable security, cash, and current liability (Acharya, Mehran \& Sundaram, 2016). This measurement focuses only on how the church fulfills its short-term commitments on a cash basis.

Iwu, Kapondoro, Twum-Darko, and Tengeh (2015), looked at non-profitable organizations (NPOs) and how to determine their sustainability and effectiveness. The study used the questions to accomplish this: "What requirements do NPOs use to assess their efficacy?" And how is sustainability integrated in the efficiency of the NPO? The research design was interpretative, taking interviews with the focus group to acquire information. In particular, two focus group interviews were conducted with an NPO's top leadership, which revealed that both economic and non-financial criteria were equally crucial to the efficiency of NPO.This finding is compatible with the literature, even though it conflicts the study's original hypothesis that the efficacy of NPO was based on non-financial factors rather than economic factors. The research also discovered that an NPO's efficacy should be regarded in two respects: first, "complete fulfillment of its mandate" and, second, "the capacity to cover costs to operate company projects."It also arose that both the capacity to cover expenses and the accomplishment of a mandate should be accomplished in a viable way (sustainability is seen as harmonizing with the natural and socio-political setting).

Mutinda, and Ngahu (2016) investigated financial sustainability for non-governmental organization (NGOs). These firms are not-for-profit making but impact life and the environment. An organization's economic sustainability is a measure of the capacity of the organisation to fulfill its economic commitments. This research aimed to determine the economic sustainability determinants of NGOs in Nakuru County, Kenya. In 56 registered NGOs working in Nakuru County, the research targeted 168 program managers, grants managers and accountants. By stratified random sampling, 
a sample size of 96 participants was chosen. Using questionnaires, data was gathered and evaluated using descriptive statistics and Pearson correlation and various regression analysis using the Social Sciences Statistical Package (SPSS) version 24. The research found that ability for mobilization of economic resources did not have a significant impact on economic sustainability in NGOs. However, inner financial control schemes in Nakuru County have been discovered to have a beneficial impact on the economic sustainability of NGOs. The management of NGOs is suggested to reinforce inner financial control mechanisms to promote transparency in the leadership of NGOs.

The impact of operational efficiency on the financial sustainability of the manufacturing companies listed in Nigeria was investigated by Osazefua (2019). Nigeria's recent economic crisis has caused an alarming decline in manufacturing companies ' financial sustainability indicators. Considered efficiency variables for the study included growth of employees, operating expenses, turnover of account receivables, turnover of inventories and turnover of assets. A secondary dataset panel ranging from 2009 to 2016 was acquired from the Bloomberg portal for 16 listed manufacturing companies. The five formulated hypotheses were tested using the Ordinary Least Square method. The findings disclosed that there was a significant negative and positive relationship between operating expenses and asset turnover about ROA. An insignificant relationship was found from the growth of employees, account receivable turnover and inventory turnover. Based on Tobin's q, there was a significant positive relationship between inventory and asset turnover. Operating expenses had a significant negative relationship. Again, it was found that the growth of employees and the turnover of account receivables were insignificant. The study suggests, based on the findings that retrenchment of employees and keeping a slender workforce might not automatically facilitate financial sustainability. The study recommended that firms aim to reduce their operating expenses and implement effective strategies addressing turnover in assets and inventories.

Iotti and Bonazzi (2015) examine the agricultural companies operating in Italy's aquaculture sector are often characterized by high investment and high capital intensity. To generate adequate cash flow, these companies need to develop structures and breeding systems to repay their investment in fixed assets. Moreover, the biological breeding cycle requires high working capital financing. Consequently, there is sometimes a discrepancy between financial and economic cycles where profit margins can vary from financial margins. Such businesses have an advantage economically but not financially sustainable. In these cases, multiple crises can force businesses to default, particularly when companies have been unable to cover debt repayment. This challenge is especially present in Italy aquaculture businesses which are often small and medium-sized enterprises (SMEs) and are therefore more difficult to access capital from the financial market. The study assesses the cost-effectiveness and financial sustainability of selected 40 companies operating in Italy's aquaculture industry over five years through a comparative analysis of financial and economic margins. The results show that these firms are capital-intensive (medium-value TA / VP is $1.16 \%$ ). Financial debt arises as to the first source of capital, then through credit systems and borrowing costs increases the financial dependence of companies. Companies are particularly absorbed in the NWC cycle, with 145.51 AP DAYS, AR DAYS being 72.75 and, I DAYS being 143.29 days, showing the operating financial cycle (I DAYS+ AR DAYS) being 70.53 days long. Profit margins are lower on average, even though they are correlated with financial margins. The research emphasizes that the worst economic model explains FCFE ( $\mathrm{F}=0.011$ and adjusted $\mathrm{R} 2=0.803)$, while FCFE $(\mathrm{F}=0.000$ and adjusted $\mathrm{R} 2=0.922$ ) is best explained by the financial model.

Mawudor (2016) studied churches in Kenya and sort to predict their financial sustainability. Financial sustainability predictors for the study were resource management, financial management, income diversification, income generation, and stakeholder/donor relationship management. The study respondents were 131 church leaders who answered self-administered questionnaires. The study resulted that financial sustainability predictors were Resource Management (.02), Financial Management (04), Income Generation (.006), Income Diversification (.001) which were significant. However, stakeholder/donor relationship failed to be a significant predictor. The study recommends remapping Church-Related Organizations ' traditional financial management strategies by drawing effective action-driven roadmaps and objectively verifiable sustainability indicators to achieve financial sustainability. 


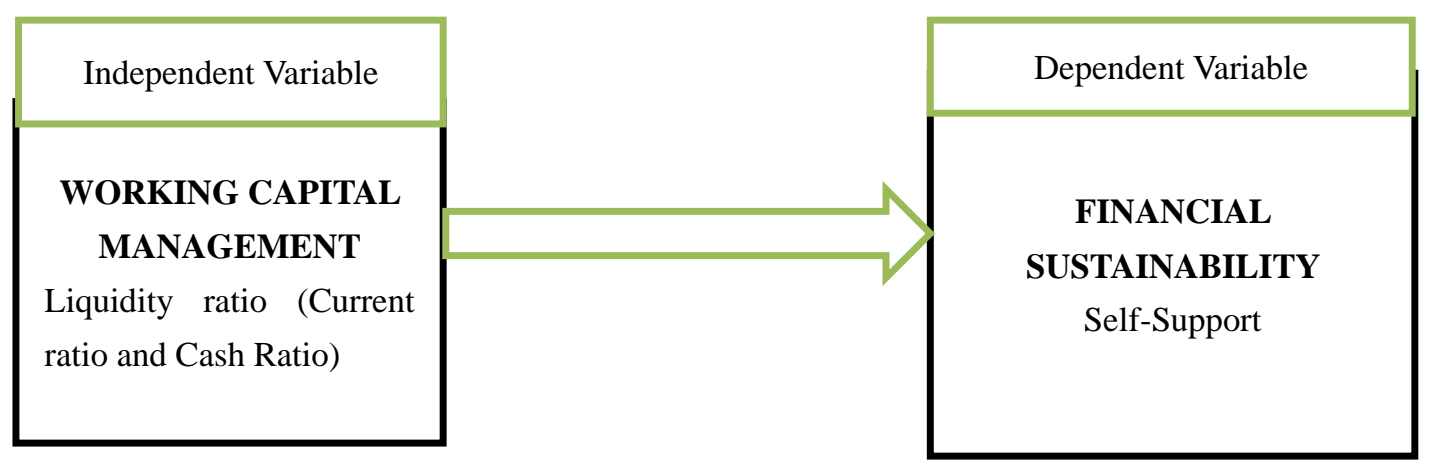

Figure 1. Research Paradigm

\section{Methodology}

Correlational research was used to develop the working capital and financial sustainability relationship. The financial data were conveniently selected from 15 out of the 31 denominational members of Christian Council of Ghana. The study used their 2013 to 2017 financial statements to calculate the analytical ratios and bivariate correlation in SPSS 23 employed in the relationship establishment. Relationship strength is determined and interpreted on the absolute correlation values of Cohen (1988) where $r=.10$ to.29 is small, $r=.30$ to.49 is medium, and $r=.50$ to 1.0 is large.

Table 1. Variables and Measurement

\begin{tabular}{ll}
\hline Variables & Measurement \\
\hline $\begin{array}{l}\text { Dependence Variable } \\
\text { Financial Sustainability } \\
\text { Independence Variable }\end{array}$ & Self-Support = Total Earned Income / Total Operating Expenses \\
Working Capital (Liquidity Ratio) & $\begin{array}{l}\text { Current Ratio = Current Assets } / \text { Current Liabilities } \\
\text { Cash Ratio = Cash/Marketable Securities / Current Liability }\end{array}$ \\
\hline
\end{tabular}

The null hypothesis of the research is:

$\mathrm{H}_{0}$ : There is no significant relationship between working capital and financial sustainability. 


\section{Data and Analysis}

The research has resulted that there is a statistically small positive significant relationship between self-support and cash ratio $\mathrm{r}=0.28, \mathrm{p}=0.12$ and statistically large positive significant relationship between self-support and current ratio $\mathrm{r}=0.58, \mathrm{p}=.036$ all at a confidence level of $95 \%$. This indicates that there is generally a positive relationship between working capital and financial sustainability among Christian denomination in Ghana. Therefore the study rejects the null hypothesis that there is no significant relationship between working capital and financial sustainability.

Table 2. Correlation Between Working Capital Management and Financial Sustainability

Correlations

Working Capital/ Liquidity Ratios

Financial Sustainability

Current Ratio Cash Ratio

\begin{tabular}{rlll} 
& Pearson & $\mathbf{0 . 5 8}$ & $\mathbf{0 . 2 8}$ \\
Correlation & & \\
Self-Support & Sig. & $\mathbf{0 3 6}$ & $\mathbf{0 1 2}$ \\
& (2-tailed) & $\mathbf{1 5}$ & $\mathbf{1 5}$ \\
\hline
\end{tabular}

*Correlation is significant at the 0.05 level (2-tailed).

Also, the churches in Ghana, nevertheless not-for-profit institution, keep much inventory that has resulted in vast differences in the ratios of current ratio and cash ratio. This study implies that the churches that are highly liquid are also financially sustainable. This study supports the assertion that churches exist because they have high liquidity (Bradford Wilcox, Cherlin, Uecker \& Messel, 2012). Financial sustainability is not an end to the existence of churches but a process for self-support. This study has given an output that when it comes to looking at the relationship between working capital and financial sustainability, there should be a positive relationship for not-for-profit firms for example churches. However, when the firm under study is profit oriented, then the relationship between working capital and profitability must be negative (Yeboah \& Yeboah, 2014; Peprah \& Riziki, 2019).

\section{Conclusion}

The study concludes that there is a large positive significant relationship between working capital management and financial sustainability is Christian churches in Ghana. The study recommends to churches in Ghana to seek an enhancing relationship between their working capital and financial sustainability to prevent a possible closure of the church. Not-for-profit organizations must seek self-support to improve their Liquidity. The church must improve its financial sustainability through various income generation ventures and diversification (Mawudor, 2016).

\section{References}

Abor, J. (2005). Working capital management and corporate profitability: Evidence from Ghana. LBS Management Review, 9(1). https://doi.org/10.4314/lbsmr.v9i1.24480

Acharya, V. V., Mehran, H., \& Sundaram, R. K. (2016). Cash holdings and bank adjustment. Journal of Banking \& Finance, 69, S56-S69.

Agyei, S. K., \& Yeboah, B. (2011). Working capital management and profitability.British Journal of Economics, Finance and Management Sciences, 2(2), 1-12.

Akoto, R. K., Awunyo-Vitor, D., \& Angmor, P. L. (2013). Working capital management and profitability: Evidence from Ghanaian listed manufacturing firms.

Amidu, M. (2007). Determinants of capital structure of banks in Ghana: an empirical approach. Baltic Journal of Management, 2(1), 67-79.

Bradford Wilcox, W., Cherlin, A. J., Uecker, J. E., \& Messel, M. (2012). No Money, No Honey, No Church: The Deinstitutionalization of Religious Life among the White Working Class. Research in the Sociology of Work, 227-250. https://doi.org/ 10.1108/s0277-2833(2012)0000023013

Cohen, J. W. (1988). Statistical power analysis for the behavioral sciences (2nd ed.). Hillsdale, NJ: Lawrence Erlbaum Associates.

Darkwah, K. A., Nortey, E. N. N., Asare-Kumi, A. A., \& Asare, K. (2019). An Estimation of Working Capital Management on Profit Using Logistic Regression and Discriminant Analysis. Journal of Economics, Management and Trade, 1-9. 
Dumestre, M. J. (2016). Financial Sustainability in Troubled Times. Financial Sustainability in US Higher Education, 41-51. https://doi.org/10.1057/978-1-349-94983-0_4

Hackett, C., \& Mcclendon, D. (2017). Christians remain world's largest religious group, but they are declining in Europe. Retrieved from:

https://www.pewresearch.org/fact-tank/2017/04/05/christians-remain-worlds-largest-religious-group-but-they-aredeclining-in-europe/

Helen S. R. (2011). Micro-businesses need support: Survival precedes sustainability. Corporate Governance: The international journal of business in society, 11(1), 15-28.

IBIS World (2019). Religious organizations industry in the US. Retrieved from: https://www.ibisworld.com/industry-trends/market-research-reports/other-services-except-public-administration/re ligious-grantmaking-civic-professional-similar-organizations/religious-organizations.html

Iotti, M., \& Bonazzi, G. (2015). Profitability and financial sustainability analysis in Italian aquaculture firms by application of economic and financial margins. American Journal of Agricultural and Biological Sciences, 15, 10(1): 18.34. https://doi.org/10.3844/ajabssp.2015.18.34

Iwu, C., Kapondoro, L., Twum-Darko, M., \& Tengeh, R. (2015). Determinants of Sustainability and Organisational Effectiveness in Non-Profit Organisations. Sustainability, 7(7), 9560-9573. https://doi.org/10.3390/su7079560

Leibson H. R. (2005). From self-sufficiency to personal and family sustainability: A new paradigm for social policy. $J$. Soc. \& Soc. Welfare, 32, 77.

León, P. (2001). Four Pillars of Financial Sustainability, Resources for Success Series, Volume 2. The Nature Conservancy, Arlington, Virginia, USA.

Mawudor, B. G. (2016). Financial Sustainability of church related organizations: An Empirical Study on Kenya. University of Basel. Globethics.net.

Mutinda, S. M., \& Ngahu, S. (2016). Determinants of Financial Sustainability for Non-Governmental Organizations in Nakuru County, Kenya. IOSR Journal of Business and Management, 18(09), 81-88. https://doi.org/10.9790/487x-1809028188

Njeri, W. R., Namusonge, G., \& Mugambi, F. (2017). Effect of working capital management on financial sustainability of government owned entities in the ministry of agriculture, livestock and fisheries (MOALF), Kenya. The strategic journal for Business \& Change Management, 4(3, 11), 147-175.

Osazefua, I. J. (2019). Operational efficiency and financial sustainability of listed manufacturing companies in Nigeria. Journal of Accounting and Taxation, 11(1), 17-31. https://doi.org/10.5897/JAT2018.0329

Peprah, W. K., Balila, E. A., Mbokani, P., Evinta, L. L., \& Riziki, A. (2019). THE mediating effects of needs and wants on the relationship between international students' financial stress and learning motivation and financial sustainability. International Journal of Economics, Commerce and Management, 7(2), 3-630.

Peprah, W. K., \& Riziki, A. (2019). The relationship between working capital and profitability: A confirmatory study from selected banks in Ghana. A paper presented at the 1st International Research Forum. On Fire: Excellence in Research, Adventist University of the Philippines, Putting Kahoy, Silang, Cavite, and April 25, 2019.

Prempeh, K. (2018). Does Working Capital Management Affect Profitability of Ghanaian Manufacturing Firms? SSRN Electronic Journal. https://doi.org/10.2139/ssrn.3289222

Van Gyampo R. E. (2015). The Church and Ghana's drive towards democratic consolidation and maturity. Journal Political Science and Public Affairs, 3(161). https://doi.org/10.4172/2332-0761.1000161

Yeboah, B., \& Yeboah, M. (2014).The Effect of Working Capital Management of Ghana Banks on Profitability: Panel Approach. International Journal of Business and Social Science, 5(10), 294-306.

\section{Copyrights}

Copyright for this article is retained by the author(s), with first publication rights granted to the journal.

This is an open-access article distributed under the terms and conditions of the Creative Commons Attribution license which permits unrestricted use, distribution, and reproduction in any medium, provided the original work is properly cited. 